\title{
熱殺菌の基本的問 題
}

\author{
白 土 志 郎 \\ （科研化学株式会社）
}

近時発酵工策が多岐に発展しから大規模化するにつれ て, 発酵工学への期待は增大しつつある。実際に多くの有 用な工学的研究がなされ発醅の分野傎献している。そ れにもかかわらず発醉生産の場と理論の間には, なおい くつかの谷間のあることが認められている。その谷間は， あるいは醸造において一層多いのではないかと考光られ る。その理由は日本の醮造は長い歴史の生んだ世界に誇 るべき独特な精致な名人芸的技術をるち, したがって極 めて複雑なこと, またその製品が微妙な官能的性質を重 要な品質要素としていること，加えて伝統をかえること の現実的なむずかしさ等であろう。筆者は若干の発酵工 業に僅かの経験をもつのみで, 醸造には体験を持たない が，かなり共通な問題があることと考劣る。その中には 除菌と殺菌（または防腐）の問題が含まれよう。筆者は 工学専門家ではなく, 発酵屋の立場から工学への接近と 応用に努めてきたので，その面で䤑造に関係ありそうな 熱殺菌に関する基本的考方方を $2 ， 3$ 紹介してみたい。

\section{（1）雑菌の耐熱性}

空中雑菌では胞子形成菌が最も耐熱性大といわれる。 普通に存在する耐熱性菌としては枯草菌, 納豆菌が知ら れている。これらの胞子をよく分散して滤紙で濾過し, 凝塊や胞子以外の植物型（生育型）の細胞を除去して耐 熱性をしらべた結果は予想外に熱に対して弱いことが判 った。例えば約 10 種類の菌を $100^{\circ} \mathrm{C}$ に保つとせいぜい 8〜18分で全部殺菌されることが知られている。

\section{（2）菌濃度と耐熱性の関係}

同じ菌の胞子でも, 溶液中の濃度が增すと耐熱性は增 大する（前項の例は $1 \mathrm{cc}$ 中約 5 千万箇で行なったもの）。 バチルス・メガテリウムの胞子で行なわれた結果は, 次 の通りであった（表中の時間は最大生存時間で, これ以 上加熱を続けると增殖をみない。処理温度は $100^{\circ} \mathrm{C}$ )。 $1 \mathrm{cc}$ 中の胞子数が約 4 箇のとき.......... 1 分$$
\text { " }
$$

百万箇のとき
$"$

1 億䇢のとき……10.10分

この関係は対数比例関係にある。式で書くと，

$$
\log _{10} N=a+b \log _{10} t
$$

ここに $N$ は胞子濃度, $t$ は耐熱時間, $a$ および $b$ は夫 々菌および環境によってきまる恒数である。

\section{（3）凝塊形成による耐熱性の增加}

初期の耐熱研究でいろいろ矛盾した結果が得られ，そ の理由をしらべたところ, 凝塊（いくつかの胞子が集っ た塊）が混じると耐熱性が増すことがわかった（前項の 実験法はこの理由から案出された)。実験によると, あ る菌の胞子の耐熱時間は凝塊のないときで 10 分, 凝塊 の混入したときで 60 分, すなわち所要殺菌時間は数倍 にも増大した。

\section{（4）懸濁液中の栄養分の影響}

例觉ば雑菌の有無の検出に用いられる肉汁培地（肉土 キス，ペプトン，食塩各 $0.5 \sim 1.0 \%$ ）に胞子を混じた 場合と，これにブドー糖を $0.1 \%$ 添加した場合とでは， 耐熱時間は後者が 2 倍位大きかった。ブドー糖のみなら ず，タンパク質やビタミン等の添加でも耐熱時間の延長 がみられる。ただし，例えばブドー糖の場合， $0.1 \%$ 以上 に添加量を增しても，それ以上耐熱時間は増大しない。 すなわち, ある程度以上濃厚な培地では, それ以上濃厚 化しても殺菌に必要な時間は増加しない。

（5） $\mathbf{p H}$ と耐熱性

培地の $\mathrm{pH}$ は耐熱性に大きな影響がある。ある例によ ると,

\begin{tabular}{c|cccc}
$\mathrm{pH}$ & $\mathrm{pH} 4.6$ & $\mathrm{pH} 6.0$ & $\mathrm{pH} 7.0$ & $\mathrm{pH} 8.0$ \\
\hline 耐熱時間 & 2 分 & 5 分 & 10 分 & 6 分
\end{tabular}

すなわち，中性で最も殺菌しにくく，アルカリ側や特 に酸性側で殺菌効果が大きくなる。

以上 5 項目から, 実際問題との関係を考察してみる。 一般に雑菌が増殖するときは小部分に集落をつくる。す なわち特定部分に菌濃度がまして, 凝塊が集る。これは パイピングのつぎ目とかバルブとか, 槽内の凹所などに 
とくに残りがちである。それ故できるだけ平滑面とする 工夫が必要となる。また，一度重大な雑菌污染が起った ら, 注意深い洗滌と, 厳重な空殺菌が必要になる。これ は集落を除去または稀釈し, 栄養分を除くことになり, この際洗湺水（最後の）が微酸性であれば空殺菌は一層 効果的になろう。

\section{（6）殺菌温度と所要時間}

殺菌温度を上げると殺菌効果は当然上り，したがって 所要殺菌時間は減少する。また強殺菌のため加熱する場 合は多かれ少なかれ培地成分の変質 (分解等)が括こる。 各種の発酵生産に执いて培地成分の变質が発酵収率を阻 害することがあり，そこで高温短時間の殺菌と低温長時 間の殺菌の優劣が問題になる。多くの研究の結果, 高温 瞬時殺菌の方が培地成分の変質度が少なくなるといらこ とが判った。第1 図はその関係を示す。図のタテ軸は雑 菌の死隇速度の対数または培地成分（この例では酵素, ビタミン) の分解速度の対数, ヨコ軸は絶対温度の逆数 を示す。 2 本の斜線の交点より左に行くほど（すなわら 殺菌温度が高(程), 殺菌速度は分解速度より大となる。 すなわち, 殺菌に必要な最小時間での成分の変質割合が 小さくなる。これに反し交点より右に行くほど,つまり 低殺菌となると, 殺菌に必要な時間内の成分の变質が大 となる。この原理を応用し連続高温（例えば $144^{\circ} \mathrm{C}$ ) 瞬 時（例觉ば 3 分）殺菌装置が実際に利用されている。

ただし，対象とする成分によって図中の斜線は異なる。 また発酵の種類により成分の分解を考慮する必要がなか ったり, 逆に少し分解させた方がよい場合もあり, 発酵 目的に応じて考虑すべきことは勿論である。アルコール 含有液などはまた別個の問題（揮発など）がある。

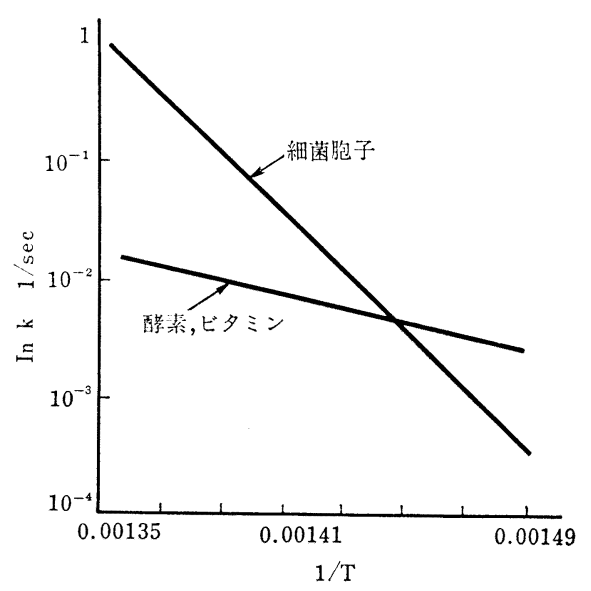

第1図加熱温度と殺菌または分解速度の関係 (Humphrey, 1964)

\section{（7）固形物混入の影響}

固形物がはいっていると内部まで殺菌温度に達するの に時間がかかるという問題が生ずる。木質に近いモデル 固形分を想定して, その内温が外液温の $63.2 \%$ まで達す る時間を, 固形物の大きさに対応し計算すると, 大体 1 $\mathrm{mm}$ 以下では考虑する必要がない程度であることが推定 された。ある工学者の算定では, 通常の発酵工業の醪で は透明な液の殺菌汇必要な温度より $1.5^{\circ} \mathrm{C}$ 位高くすれば 足りるとされている。醇造の場合はどらであろうか?大 粒殼粒等では, ポイントはもっと異なるかもしれない。

以上，ごく簡単に発酵の実際と工学の谷間をつなぐ熱 殺菌の 2,3 の問題点を描写したが, 醸造の実際的問題 点は専門諸家よりの御教示を打願いしたい。

\title{
- 熱殺菌と除菌
}

\section{除菌の理論とその醸造への応用}

\author{
江 角 新 一 郎
}

(科研化学株式会社)

近年無菌空気の需要は醸造, 発酵, 食品, 製薬等の諸 工業はもちろん, 病院その他医療機関の無菌室や手術室, さらに一般建造物中の空気浄化等々広、分野に打いて急 速に高まっている。空気中には無数の塵埃や排ガスと共
に多種多様の微生物が浮遊しているので, 無菌空気にす るにはこれらの微生物を除去または殺菌しなければなら ない。このため従来一般に綿または炭末を充填したェア フィルターが使用されていたのであるが，戦後グラスウ 